\title{
Psychiatric Nursing
}




\title{
Psychiatric Nursing A Therapeutic Approach
}

\author{
Edited by \\ Peggy Martin
}






(1) Peggy Martin and the Individual Contributors 1987

All rights reserved. No reproduction, copy or transmission of this publication may be made without written permission.

No paragraph of this publication may be reproduced, copied or transmitted save with written permission or in accordance with the provisions of the Copyright, Designs and Patents Act 1988, or under the terms of any licence permitting limited copying issued by the Copyright Licensing Agency, 90 Tottenham Court Road, London WIT 4LP.

Any person who does any unauthorised act in relation to this publication may be liable to criminal prosecution and civil claims for damages.

The authors have asserted their rights to be identified as the authors of this work in accordance with the Copyright, Designs and Patents Act 1988.

Published by

PALGRAVE MACMILLAN

Houndmills, Basingstoke, Hampshire RG21 6XS and

175 Fifth Avenue, New York, N. Y. 10010

Companies and representatives throughout the world

PALGRAVE MACMILLAN is the global academic imprint of the Palgrave Macmillan division of St. Martin's Press, LLC and of Palgrave Macmillan Ltd. Macmillan $\bullet$ is a registered trademark in the United States, United Kingdom and other countries. Palgrave is a registered trademark in the European Union and other countries.

ISBN 978-0-333-43842-8 ISBN 978-1-349-09408-0 (eBook) DOI 10.1007/978-1-349-09408-0

This book is printed on paper suitable for recycling and made from fully managed and sustained forest sources.

A catalogue record for this book is available from the British Library.

$\begin{array}{llllllll}13 & 12 & 10 & 9 & 8 & 7 & 6 & 5\end{array}$

$\begin{array}{llllllll}10 & 09 & 08 & 07 & 06 & 05 & 04 & 03\end{array}$

\section{For Graham with Love}




\section{CONTRIBUTORS}

Carl Dykes, RMN, is currently Charge Nurse in the Department of Child and Family Psychiatry, Children's Day Hospital, London.

Lynn Harris, BSc(Hons), RGN, RSCN, HV, is currently a clinical nurse specialist in the Guy's Support Team based at Guy's Hospital, London.

Helen Lewer, BSc(Hons), RGN, RSCN, RNT, is currently Tutor at The Nightingale School, St Thomas's Hospital, London.

Bob Payne, RGN, RMN, FETC, RCNT, is currently a nurse teacher.

Neil Vermaut, BSc, RMN, is currently Staff Nurse at Rees House Day Hospital, Croydon.

\section{CRITICAL COMMENTERS}

Dr Justus Akinsanya, PhD, BSc(Hons), STD, RNT, RGN, Orth Nurs Cert (Hons), Cert Dermatological Nursing, BTA Cert, is currently Acting Head of the Department of Nursing and Social Service, Dorset Institute of Higher Education, Poole, Dorset.

Martin Brown, RMN, RCNT, RNT, Dip N Ed, Cert Behavioural Psychotherapy, is currently Director of Nursing Services, Adult Mental Health, West Lambeth Health Authority, London.

Philip Burnard, MSc, RMN, RGN, Dip N Cert Ed, RNT, is currently Lecturer in the Nursing Studies Department at the University of Wales College of Medicine, Cardiff.

Dr P. Carr, BA, PhD, RMN, RGN, RNT, was formerly Head of Nursing Studies at Manchester Polytechnic and is currently General Secretary of the Registered Nursing Homes' Association.

Reg Everest, RMN, RGN, RNT, is currently Education Officer at The English National Board of Nursing, Midwifery and Health Visiting, London.

Helen Lewer, $\mathrm{BSc}$ (Hons), RGN, RSCN, RNT, is currently Tutor at The Nightingale School, St Thomas's Hospital, London.

Barbara McNulty, RGN, SCM, FRCN, is currently a bereavement counsellor working as a freelance.

David Passey, RMN, Dip Professional Studies, Cert Ed, RNT, is currently Education Officer (Mental Nursing) at The English National Board of Nursing, Midwifery and Health Visiting.

$P$. Tibbles, RMN, is currently Director of Nursing Services at The Bethlem Royal Hospital, Beckenham, Kent.

John Tingle, BA Law(Hons), Cert Ed, is currently Lecturer in Law at the Worcester Technical College, Deansway, Worcester.

Brian Woollatt, MBE, RGN, RMN, was formerly Senior Clinical Nurse at The Drug Dependence Clinical Research and Treatment Unit of The Bethlem Royal Hospital, Beckenham, Kent. 


\section{Contents}

Contributors

Critical Commenters

Foreword

xiv

Preface

xvi

Acknowledgements

xvii

Part 1 Concepts 1

1 Introduction 3

2 The role of the psychiatric nurse 7

Introduction $\quad 7$

The nurse stereotype $\quad 7$

The nurse as an individual $\quad 7$

Nursing as a learning process $\quad 7$

The roles of the nurse 8

Fact sheet 9

3 The nurse-patient relationship 11

Introduction 11

$\begin{array}{ll}\text { Trust } & 11\end{array}$

Confidentiality 12

The nurse-patient relationship 12

Burn-out 14

4 The nurse, the patient and the law 17

by Bob Payne

Why be concerned with the law? $\quad 17$

What is the law? 17

What about the different courts? 18

Powers of restraint 19

Case study $\quad 19$

Negligence and liability $\quad 22$

Case study 22

Standards of care $\quad 23$

Case study $\quad 24$

Consent and confidentiality $\quad 25$

Case study $\quad 26$

Complaining and defamation $\quad 27$

Case study $\quad 27$

The nurse as a witness $\quad 29$

Case study $\quad 29$ 
5 The multi-disciplinary team in mental health 32

Introduction 32

Teamwork 32

The roles of team members $\quad 32$

A therapeutic alliance $\quad 32$

Supportive roles of team members 33

Members of the multi-disciplinary team 33

$6 \quad$ The therapeutic use of self 38

Introduction $\quad 38$

A model of self-awareness $\quad 39$

The value of self-awareness $\quad 40$

The mental, physical, psychosocial and $\quad 40$ spiritual aspects of self

The development of nurse-patient 40 communication skills for therapeutic purposes

Patient profile $\quad 42$

$7 \quad$ Conceptual models in nursing 49

Why use a model? $\quad 49$

What is a model? 49

Function of a model 49

A developmental model $\quad 50$

An adaptation model $\quad 53$

An activities-of-living model $\quad 54$

A self-care model $\quad 55$

Summary $\quad 56$

$8 \quad$ The nursing process 59

Introduction $\quad 59$

Assessment $\quad 61$

Fact sheet: Information-gathering techniques $\quad 66$

Planning $\quad 69$

Implementation $\quad 71$

Fact sheet: Some nursing interventions $\quad 73$

Evaluation $\quad 75$

9 The nurse's role in group therapy 78

Introduction $\quad 78$

Selection of group members $\quad 78$

Starting a group $\quad 80$

Working phase $\quad 81$

Termination 83

Dealing with particular problems within the 83 group

Leadership in groups $\quad 84$

$10 \quad$ The nurse's therapeutic role in physical 87

treatments and procedures

$\begin{array}{ll}\text { Introduction } & 87\end{array}$

Reassurance of patient $\quad 88$

Electroconvulsive therapy $\quad 88$

Giving medicine $\quad 90$

Side effects of drugs $\quad 90$ 
The influence of the hospital environment on $\quad 92$ the patient

The fear of death

Therapeutic role of the nurse

The influence of the patient's illness on the 93 nurse's attitude

The patient's reaction to his illness 93

The nurse-patient relationship 93

Nursing interventions 94

The different behaviours of patients $\quad 94$

The needs of visitors 96

The provision of a link with other professional $\quad 96$ services

Helping the patient to express his emotions $\quad 97$

\section{Part 2 Care 99}

12 Nursing care of the person who is 101 depressed

Introduction 101

Patient profile 102

Use of Peplau's developmental model $\quad 106$

Depression following childbirth $\quad 109$

by Helen Lewer

Patient profile $\quad 110$

Use of Orem's self-care model $\quad 115$

Plan of nursing care 115

Implementation 122

Evaluation 122

Discussion 122

13 Nursing care of the person who is suicidal 125

Introduction 125

Patient profile 125

Use of Roy's adaptation model $\quad 125$

Plan of nursing care $\quad 129$

Nursing intervention 131

Evaluation 132

Causes of suicide 133

Maintaining a safe environment for the $\quad 133$ suicidal patient

Fact sheet: Methods of committing suicide $\quad 134$

Fact sheet: Clues to suicide 134

Fact sheet: Suicide $\quad 134$

$14 \quad$ Nursing care of the patient who is anxious 137

by Neil Vermaut

Introduction 137

Patient profile $\quad 138$

Assessment 143

Plan of nursing care 143

Implementation of plan of nursing care $\quad 143$

Evaluation 144

Relaxation techniques $\quad 144$ 
Nursing care of the patient who is phobic

Patient profile $\quad 146$

Assessment 151

Plan of nursing care $\quad 151$

Implementation of plan of nursing care $\quad 151$

Evaluation $\quad 152$

$15 \quad$ Nursing care of the patient who is 154

obsessional

by Neil Vermaut

Introduction 154

Patient profile $\quad 155$

Assessment 161

Plan of nursing care $\quad 161$

Implementation of plan of nursing care $\quad 161$

Evaluation $\quad 162$

16 Nursing care of the attention-seeking 164

\section{patient}

Introduction $\quad 164$

Patient profile $\quad 164$

Use of Peplau's developmental model $\quad 170$

Setting limits $\quad 171$

Plan of nursing care $\quad 172$

$17 \quad$ Nursing care of the elderly mentally $\quad 175$

impaired patient

Introduction 175

$\begin{array}{ll}\text { Patient profile } & 176\end{array}$

Use of the Roper-Logan-Tierney 178

activities-of-living model

Maintaining a safe environment $\quad 178$

Plan of nursing care $\quad 178$

$\begin{array}{ll}\text { Nursing intervention } & 178\end{array}$

$\begin{array}{ll}\text { Communicating } & 179\end{array}$

Plan of nursing care $\quad 179$

$\begin{array}{lr}\text { Nursing intervention } & 179\end{array}$

Evaluation 180

Breathing $\quad 180$

Eating and drinking $\quad 180$

Plan of nursing care $\quad 180$

Nursing intervention $\quad 180$

Evaluation $\quad 180$

Eliminating $\quad 181$

Plan of nursing care $\quad 181$

$\begin{array}{ll}\text { Nursing intervention } & 181\end{array}$

Evaluation $\quad 181$

Personal cleansing and dressing $\quad 181$

Plan of nursing care $\quad 181$

Nursing intervention $\quad 181$

Evaluation $\quad 182$

Controlling body temperature $\quad 182$

$\begin{array}{ll}\text { Mobilising } & 182\end{array}$

Plan of nursing care $\quad 182$

Nursing intervention $\quad 182$ 
Evaluation $\quad 182$

Working and playing $\quad 182$

Plan of nursing care $\quad 182$

Nursing intervention $\quad 183$

Evaluation 183

Expressing sexuality 183

Plan of nursing care $\quad 183$

Nursing intervention $\quad 183$

Evaluation 184

Sleeping $\quad 184$

Plan of nursing care $\quad 184$

Nursing intervention $\quad 184$

Evaluation 184

Fact sheet: Elderly patients $\quad 184$

Fact sheet: Reality orientation $\quad 185$

Fact sheet: More on reality orientation $\quad 186$

'Poetic thoughts of an old woman' 186

18 Nursing care of the dying patient 190

by Lynn Harris

Introduction $\quad 190$

Patient profile 191

Use of the Roper-Logan-Tierney 196

activities-of-living model

Maintaining a safe environment 196

Plan of nursing care 196

Nursing intervention 196

Evaluation 197

Communicating 197

Plan of nursing care 197

Nursing intervention 197

Evaluation 198

Breathing 198

Plan of nursing care 198

Nursing intervention 199

Evaluation 199

Eating and drinking 199

Plan of nursing care 199

Nursing intervention 199

Evaluation 199

Eliminating 199

Plan of nursing care 199

Nursing intervention 200

Evaluation 200

Personal cleansing and dressing 200

Plan of nursing care 200

Nursing intervention 200

Evaluation 201

Controlling body temperature 201

Mobilising 201

Plan of nursing care 201

Nursing intervention 201

Evaluation 201

Working and playing 201

Expressing sexuality 201 
$\begin{array}{ll}\text { Plan of nursing care } & 201 \\ \text { Nursing intervention } & 202 \\ \text { Evaluation } & 202 \\ \text { Dying } & 202 \\ \text { Plan of nursing care } & 202 \\ \text { Nursing intervention } & 202 \\ \text { Evaluation } & 203\end{array}$

19 Nursing care of the patient who is violent 205

Introduction 205

Boettcher's model 205

Patient profile $\quad 207$

Plan of nursing care, nursing intervention 212 and evaluation

Prevention of violence 213

Dealing with violent behaviour 214

Fact sheet: The patient who is violent 215

20 The child, the problem and the family 218

by Carl Dykes

Introduction $\quad 218$

The family as a system $\quad 219$

The systemic context of the symptom 221

Patient profile $\quad 222$

Systemic formulation of family problem $\quad 224$

Patient profile $\quad 225$

Systemic formulation of family problem $\quad 227$

Some implications for a therapeutic approach $\quad 227$

21 Nursing care of the patient with 230

anorexia nervosa

Introduction $\quad 230$

Patient profile $\quad 231$

Use of behavioural approach $\quad 237$

Plan of nursing care $\quad 237$

Implementation $\quad 237$

Evaluation $\quad 239$

22 Nursing care of the alcoholic patient 241

Introduction $\quad 241$

Patient profile $\quad 242$

Use of Orem's self-care model 246

Plan of nursing care $\quad 247$

Implementation $\quad 248$

Evaluation $\quad 249$

Detecting the early signs of alcoholism 250

$23 \quad$ Nursing care of the patient who abuses 252 drugs

by Neil Vermaut

Introduction $\quad 252$

Patient profile $\quad 253$

Assessment 259

Plan of nursing care $\quad 259$

Implementation of treatment 259 
Evaluation

Fact sheet: Actions and effects of some drugs 261

Fact sheet: Drug abusers

24 Nursing care of the patient who is

overactive

Introduction

263

Patient profile $\quad 263$

Use of Roy's adaptation model 264

Plan of nursing care $\quad 264$

Nursing intervention $\quad 270$

Evaluation $\quad 271$

Fact sheet: The overactive patient 272

25 Nursing care of the patient who is suspicious 274

Introduction 274

Patient profile $\quad 274$

Use of Roy's adaptation model 280

Plan of nursing care $\quad 280$

Nursing intervention $\quad 280$

Evaluation $\quad 282$

Fact sheet: The suspicious patient 282

26 Nursing care of the patient who is 285

withdrawn

Introduction 285

Patient profile $\quad 285$

Use of Peplau's developmental model 291

Plan of nursing care 293

27 Nursing care of the patient who is out of 296

touch with reality

Introduction 296

Patient profile $\quad 297$

Use of Roy's adaptation model 303

Plan of nursing care $\quad 303$

Implementation $\quad 303$

Evaluation 304

Nursing the patient who is out of touch 305 with reality

Fact sheet: The patient who is out of touch 305 with reality

28 Nursing care of the patient who is 307

institutionalised

Introduction $\quad 307$

Patient profile $\quad 308$

Use of Orem's self-care model $\quad 314$

Plan of nursing care $\quad 314$

Implementation $\quad 315$

Evaluation $\quad 316$

List of useful addresses $\quad 318$ 


\section{Foreword}

The mentally ill in hospitals, in community facilities and in home services count on nurses to help them to solve their interpersonal and psychosocial problems. Meeting this expectation of patients is the purpose of psychiatric nursing practice. In order to provide useful nursing services, nurses require theoretical understanding of the common presenting problems of patients, as presented in this textbook.

The problems of mentally ill patients do not arise overnight. They consist in patterns of behaviour, evolved as adaptive response to experiences earlier in life. Individuals acquire behaviour patterns in interactions with persons who are significant to them in some way. Such interactions occur during child-rearing encounters in the home, during contacts with peers and teachers in school, in work situations and in other social institutions such as churches. Some of these patterns and behavioural acts, which are variants of a pattern, endure throughout life and serve to assure continuing growth and constructive living in the community. For the mentally ill, however, the situation is otherwise.

Persons who become mentally ill generally acquire behaviours important to them in terms of relief from anxiety and their psychosocial survival as they perceive it at a given time. These patterns of behaviour, which in earlier situations had great utility, persist and tend to become automatic, to be used without thought. This occurs, in part, because the behaviours are known, familiar and provided relief from anxiety. Such behaviours continue to be used, even though they are maladaptive in terms of continuing personal development and living in the community, for the patients are unaware that such behaviours are dysfunctional. One patient, after sustaining marked improvement in her condition, referred to her previous behaviour as her 'trapadaptation', an apt characterisation.

Maladaptive behaviours reflect lacks and gaps in the development of intellectual, interpersonal and social skills in accord with age, in-born capacities and social expectations. They prevent or limit social living within the community. Such inept behavioural patterns are replayed, recurringly, within the in-patient milieu, by patients in their interactions with other patients, nurses and other staff members of the hospital. Helping patients to recognise and to resolve these difficulties is the main challenge of nurses employed in psychiatric services.

Nurses do not change the behaviour of patients. What nurses do is to initiate, assist and support patients in their efforts to change their own behaviour. Nurses do this first by defining the nature of the problems of each patient. This requires application of the nursing process and of theory, 
as described in this textbook. Armed with theoretical understanding of presenting difficulties of patients, nurses then use nurse-patient interactions as opportunities to generate self-awareness in patients as a basis for patients gradually to reshape their own behaviour. Nurses also assist patients to know, to test and therefore to acquire new health-seeking behaviours as maladaptive patterns are gradually and slowly given up.

The work of nurses in psychiatric services is indeed disciplined, purposeful and difficult. It requires continuing self-study by the nurse so that patients are not used to meet the needs of the nurse. It requires theory so that the nurse's understanding of problems is guided by the best available scientific knowledge. It requires that the nurse's attention is focused on getting to know the patient as a person, so that the patient's dilemmas are appreciated while latent capacities for growth are tapped as new skills are developed. It requires that the nurse supports separateness of identity of both nurse and patient and yet uses the connectedness of the nurse-patient relationship for purposes beneficial for the patient.

Promoting changes in behaviour, in oneself and in others, is an elusive goal, limited by the available knowledge, and therefore a stimulating challenging field of work for intelligent enterprising nurses. This textbook will assist student nurses to acquire some of the basic intellectual tools with which to begin a career in this important, socially relevant and interesting component of nursing. 


\section{Preface}

Psychiatric Nursing: A Therapeutic Approach centres on the skills used by psychiatric nurses in caring for patients with psychological problems in both hospital and community settings.

The book is primarily designed to help nurses to think about what they do and to clarify their roles and functions within the multi-disciplinary setting. The focus on nursing as an activity in its own right is intentional and deliberate, while recognising the importance of a wide knowledge gained from a number of different disciplines.

The book emphasises the significance of the therapeutic use of self in communicating with patients productively and in carrying out the process of nursing effectively. The first part of the book is concerned with the nurse's therapeutic approach to care as a member of a multi-disciplinary team and as an individual. The second part of the book explores the application of patient care through the use of patient profiles and the application of different nursing models and approaches to care.

Purley, 1987

P.M. 


\section{Acknowledgements}

I should like to thank Elizabeth Horne, formerly Senior Editor, Macmillan Education, for inviting me to write this book, Mary Waltham, Senior Editor, and Sheila Collins OBE for their guidance, support and ideas which have been incorporated into the text.

I am deeply grateful to Professor Hildegard E. Peplau, not only for agreeing to write the foreword to this book but also for enabling me to develop a greater understanding of psychiatric nursing through her numerous publications. Thanks are also due to many colleagues and members of the multidisciplinary team who have offered comments and contributions: Dr Thomas Barnes, Dr Kate Tress, Maureen Ryan, Lyleanne Hopkins, Alison Cook, Jenny Harwood, Pauline Tanner, Niki Muir, Lynn Strickland, Fred Seechahid, Charlie Wood and the Reverend Geoffrey Johnson.

I should like to thank the library staff at the Royal College of Nursing, and Jacky Boothby and Margaret Paull of Horton Hospital, for their assistance.

The writing of this book has involved many discussions with learners and ward managers and I thank them for sharing their ideas and concerns.

I should like to thank two of my former colleagues for their support, John Scadden, Principal Nursing Officer (Research), and Stella Desai, Clinical Teacher, Horton Hospital, and finally Doris Crouch for typing the manuscript.

The author and publishers wish to thank the following who have kindly given permission for the use of copyright material:

Random House Inc. Alfred A Knopf Inc. for adaption of figure after Sabin, 1954, Role theory. In: Handbook of Social Psychology, Vol. 1, 1st edn (eds Lindzey and Aronson), Addison-Wesley, Reading, Massachusetts.

Rodale Press Inc. for figure from J. I. Rodale, The Synonym Finder, Copyright (C) 1978 by Rodale Press Inc.

Mayfield Publishing Company for 'The Johari window' from J. Luft, Group Processes: An Introduction to Group Dynamics, Copyright (C) 1984, 1970, 1963 by Joseph Luft.

John Wiley and Sons Ltd for material from Senior Nurse, 3, No. 2, July 1985.

Every effort has been made to trace all the copyright holders but, if any has been inadvertently overlooked, the publishers will be pleased to make the necessary arrangement at the first opportunity. 